\title{
Investigation of indoor air quality in university libraries in terms of gaseous and particulate pollutants in Bartin, Turkey
}

\author{
Gülten Güneş® • Nesibe Yalçin • Huriye Çolaklar
}

Received: 23 June 2021 / Accepted: 22 January 2022 / Published online: 19 February 2022

(C) The Author(s), under exclusive licence to Springer Nature Switzerland AG 2022

\begin{abstract}
Indoor air quality (IAQ) was investigated in two libraries of Bartin University. Particle matter, TVOC, and $\mathrm{CH}_{2} \mathrm{O}$ were measured simultaneously in different rooms of the libraries. Measurements were made by PCE-RCM 11 measuring device. They were conducted monthly between September 2019 and October 2020 for 2 weeks for each library. TVOC mean concentration was higher than the limit value reported by Seifert et al. (1999). $\mathrm{PM}_{2.5}$ and $\mathrm{PM}_{10}$ concentrations were higher in winter unlike TVOC and $\mathrm{CH}_{2} \mathrm{O}$ concentrations. The indoor seconder blowing dust was detected to be the most important source of particulate matter in the indoor environment. On the other hand, it was thought that the pollutants in the gas phase were affected by indoor and outdoor air temperature, indoor/outdoor air exchange rate, and indoor/outdoor pollutant sources. The parameters
\end{abstract}

Supplementary information The online version contains supplementary material available at https://doi. org/10.1007/s10661-022-09818-8.

G. Güneş $(\bowtie)$

Environmental Engineering Department, Bartin University, Bartin, Turkey

e-mail: ggunes@bartin.edu.tr

N. Yalçin

Computer Engineering Department, Bartın University,

Bartın, Turkey

H. Çolaklar

Information and Document Management Department, Bartin University, Bartin, Turkey changed during the day and in different rooms of the libraries. Pollutants did not pose any hazard on human health, since the calculated HQ and $\mathrm{HI} \leq 1$ for both exposure groups. The indoor air of the libraries was detected to be slightly polluted and bad according to the IAQI and IEI, respectively. On the other hand, the indoor air quality of the libraries was good in terms of all parameters according to the IAQC.

Keywords Indoor air quality - Total volatile organic compounds $\cdot$ Formaldehyde $\cdot$ Health risks

\section{Introduction}

Indoor air quality (IAQ) is a term that expresses to the quality of the air in a closed environment by thermal comfort conditions (temperature and relative humidity) and the pollutant concentrations. The indoor air pollutants (i.e. harmful gases, particulate matter, biological agents, and volatile organic compounds) affect occupants' health situation, comfort, and performance negatively and cause harmful effects on the materials. Poor IAQ can lead to loss of performance, health problems such as poisoning, allergic reactions, and sick building syndrome. High levels of pollutants and humidity can create some harmful effects on materials, collections, and antiquities such as rot, deterioration, colour change, corrosion, and so on.

University libraries are environments that are used extensively by students and also contain valuable 
works. Therefore, IAQ will affect directly students' health and performance. Many studies have been conducted to analyse the IAQ in library buildings for the users (Fantuzzi et al., 1996; Gunes et al., 2015; Hizrri et al., 2015; Yang, 2017; Li et al., 2017; Wu et al., 2018; Sahu et al., 2019; Zhang, 2019). The effect of $\mathrm{PM}_{10}$ on the health of library staffs and users was investigated in and its limit values were observed to be exceeded during exam periods (Gunes et al., 2015). The functionality of use areas and the necessity of clean air in the design of the ventilation systems in the library rooms have been pointed out in another research (Wu et al., 2018). It has been showed that IAQ has a positive effect on satisfaction and efficiency of occupants as a result of the surveys (Zhang, 2019). As seen from these studies, libraries have insufficient ventilation and unacceptable IAQ and present a health risk for employees and users. To ensure acceptable IAQ, the air temperature and relative humidity should be kept at the desired level for health, dust collectors and air cleaners should be used, ventilation should be increased, and most importantly, pollutant sources should be controlled (Yalcin, 2017).

Paints, furniture, varnishes, wood preservatives, disinfectants, aerosol sprays, cleaning products, air fresheners, hobby materials, dry-cleaning clothes, combustion products, pesticides, office equipment, and adhesives are the most important sources of volatile organic compounds (VOC) for the indoor environment (EPA, 2020a). Acetone, formaldehyde, acetaldehyde, glyoxal, benzaldehyde, and methyl isobutyl ketone are related to furniture, floor coverings, wall coverings, and building materials. VOCs and formaldehyde are highly toxic and carcinogenic compounds cause respiratory diseases (Ashford \& Caldart., 2001; Bu et al., 2016; Wu et al., 2018). It has been reported that high concentrations of VOC and formaldehyde are risk factors for asthma and rhinitis and may even be associated with cancers related to skin, lung, melanoma, and endocrine (Kelly \& Hussel, 2011; Hulin et al., 2012; Bakian et al., 2015; Boeglin et al., 2006; Eigurenfernandez et al., 2010; Martins et al., 2012; Baccioglu \& Kalpaklioglu, 2007; Klinmalee et al., 2009). Formaldehyde $\left(\mathrm{CH}_{2} \mathrm{O}\right)$ is a colourless, pungent, poisonous gas. It has many harmful effects on respiratory, digestive, and nervous systems (Yalcin, 2017; Unsaldi \& Çiftçi, 2010). The most important $\mathrm{CH}_{2} \mathrm{O}$ sources in the indoor air are the resins used for the production of composite wood products (i.e. parquet plywood, chipboard, and medium density fibreboard), building materials and insulation materials, glues, permanent printing fabrics, paints and coatings, plastics, varnishes, and paper products (Nielsen et al., 2010). Indoor sources of particulate matter (PM) are cigarette smoking, cooking, and use of stoves, heaters, and fireplaces (EPA, 2020b). $\mathrm{PM}_{2.5}$ refers to PM that have a diameter of less than $2.5 \mu \mathrm{m}$. High $\mathrm{PM}_{2.5}$ concentrations cause significant health effects on bronchitis, lungs, and heart. $\mathrm{PM}_{10}$ (diameter $\leq 10 \mu \mathrm{m}$ ) pollution can settle deep into the lungs and cause serious health problems (Wang, 2012). Printers, computers, scanners, and photocopiers are considered to be the most important causes of VOCs and ultrafine particles $(d<0.1 \mathrm{~mm})$ (Gaur et al., 2018; Lee et al., 2001; Kagi et al., 2007; Horemans et al., 2010).

Indoor limits/standards have been set by authority organisations and independent agencies such as World Health Organization (WHO) and Researchers and Environmental Protection Agency (EPA) to protect primarily the public health, including the health of "sensitive" people with lung disease (such as asthma, cough, and wheeze), children, and the elderly. Limit values related to parameters affecting IAQ are summarised in Table 1. Good environmental conditions are critical in the protection of cultural collections such as libraries, archives, and museums (Schäfer, 2014).

In this study, it was aimed to determine the indoor air quality in 2 libraries in the old and new campuses of Bartin University. In the study, it was aimed to measure the pollutant concentrations, determine the quality index, and evaluate the health risk analysis

Table 1 Indoor air quality standard values

\begin{tabular}{lll}
\hline Parameter & Indoor air limit & Reference \\
\hline $\mathrm{PM}_{2.5}$ & $25 \mu \mathrm{g} / \mathrm{m}^{3}$ (24 h avg.) & (WHO, 2010) \\
& $10 \mu \mathrm{g} / \mathrm{m}^{3}$ (annual avg.) & (WHO, 2010) \\
$\mathrm{PM}_{10}$ & $50 \mu \mathrm{g} / \mathrm{m}^{3}$ (24 h) & (WHO, 2010) \\
& $20 \mu \mathrm{g} / \mathrm{m}^{3}$ (1 year) & (WHO, 2010) \\
TVOC & $600 \mu \mathrm{g} / \mathrm{m}^{3}(8 \mathrm{~h})$ & (Burnett, 2005; \\
& $300 \mu \mathrm{g} / \mathrm{m}^{3}(8 \mathrm{~h})$ & Ugranl \\
& & et al., 2015) \\
& & (Seifert et al., \\
& & 1999) \\
$\mathrm{CH}_{2} \mathrm{O}$ & $<100 \mu \mathrm{g} / \mathrm{m}^{3}$ (30-min avg.) & (WHO, 2017) \\
Temperature & $24.5-28^{\circ} \mathrm{C}$ (summer) & (ASHRAE, 2004) \\
& $23-25.5{ }^{\circ} \mathrm{C}$ (winter) & \\
Humidity & $30-80 \%$ (summer) & (HC, 1995) \\
& $30-55 \%$ (winter) &
\end{tabular}


under the current conditions, without interfering with the library conditions. In addition to the effect of building age on indoor air quality, factors affecting indoor air quality were evaluated.

\section{Material and methods}

\section{Site description}

In this study, measurements were made in libraries located in 2 different campuses of Bartin University. Both libraries are located close to the village settlement. Library I (Libr 1) is located on the first floor of a 40-year-old building. In the entrance part, the floor is covered with stone and other places (reading room and bookshelf) are covered with wood and PVC material. Library II (Libr 2) is located in the basement of a 5-year-old building and the floors of all rooms are covered with stone. Both libraries are ventilated by natural ventilation method. In the winter season, ventilation was done for up to $10 \mathrm{~min}$ in the mornings and was usually kept closed during the day. The windows were usually open during the day in autumn and summer seasons. Heating is done with natural gas system. Measurements were made simultaneously in different library rooms (reading room, entrance hall, book holding).

\section{Monitoring and measurement}

Measurements were conducted monthly between September 2019 and October 2020 for 2 weeks for each library. They were made 4 days a week for $2 \mathrm{~h}$ in the morning and $2 \mathrm{~h}$ in the afternoon. Values were recorded every $10 \mathrm{~min}$. Within the scope of the preventions taken during the COVID-19 pandemic duration, measurements could not be made in the spring months. Temperature, relative humidity, $\mathrm{PM}_{2.5}, \mathrm{PM}_{10}$, total volatile organic compounds (TVOCs), and formaldehyde $\left(\mathrm{CH}_{2} \mathrm{O}\right)$ were measured simultaneously in all rooms with the PCE-RCM 11 (Figure S1). The measuring device was placed at a height of 1-1.5 from the floor in the middle of the room, away from the walls and windows. Care was taken to ensure that the measuring point represents the entire room. This device uses laser scattering weight test method to detect $\mathrm{PM}_{2.5} / \mathrm{PM}_{10}$ (mass concentration range $0-2000 \mu \mathrm{g} / \mathrm{m}^{3}$, resolution $\left.1 \mu \mathrm{g} / \mathrm{m}^{3}\right)$. TVOC measures in the range of $0-9.9 \mathrm{mg} / \mathrm{m}^{3}$ (accuracy: $\pm 5 \%$ of the measuring range) with the semiconductor sensor, and $\mathrm{CH}_{2} \mathrm{O}$ measures in the range of $0-5 \mathrm{mg} / \mathrm{m}^{3}$ (accuracy: $\pm 5 \%$ of the measuring range) with the fuel cell sensor. Temperature is measured between -20 and $70{ }^{\circ} \mathrm{C}$ (accuracy: $\pm 2{ }^{\circ} \mathrm{C}$ ) with the PT100 sensor. Humidity is measured in the range of $0-100 \% \mathrm{RH}$ (accuracy: $\pm 5 \% \mathrm{RH}$ ). In order to ensure the quality and control of the measurements, the devices were calibrated by the vendor in an external laboratory in accordance with ISO 9001, National Institute of Standards and Technology (NIST), and German Accreditation Body GmbH (DAkkS).

\section{Statistical analysis}

All calculations and statistical analyses in the study were made with the SPSS 26 package program. Independent samples $t$-test and Mann-Whitney $\mathrm{U}$ tests were applied to the data set to determine whether the determined mean values were statistically significant. Before this tests, Kolmogorov-Smirnov, ShapiroWilk and one-way ANOVA tests were applied, respectively, to determine whether the data set showed normal and homogeneous distribution.

Human health risk assessment

Health risk assessment was carried out to estimate the risks that may arise from exposure to toxic pollutants. In order to make a risk assessment, the exposure concentration must be determined. Exposure occurs in different ways, including breathing, feeding, and dermal contact. After determining the exposure concentration, carcinogenic or non-carcinogenic risk assessment was performed using the equations reported in the literature.

\section{Estimation of exposure}

Exposure concentration can be calculated according to the latest methodology (inhalation dosimetry methodology) reported by EPA (EPA, 2009). This methodology explains that, contrary to the previous methodology, in which body weight and respiratory rate were taken into account, the amount of chemicals reaching the target area via the inhalation is directly 
related to the chemical concentration exposed (EPA, 2009; Rovira et al., 2010). The chronic exposure concentration $\mathrm{CE}_{\mathrm{C}}\left(\mu \mathrm{g} / \mathrm{m}^{3}\right)$ can be calculated according to Eq. (1) (EPA, 2009; Rovira et al., 2010).

$\mathrm{CE}_{\mathrm{c}}=\frac{C \times T_{\mathrm{e}} \times F_{\mathrm{e}} \times E_{\mathrm{d}}}{T_{\mathrm{a}}}$

where $C$ is the pollutant concentration in air $\left(\mu \mathrm{g} / \mathrm{m}^{3}\right)$, $T_{\mathrm{e}}$ is the exposure time (h/day), $F_{\mathrm{e}}$ is the exposure frequency (days/year), $E_{\mathrm{d}}$ is the exposure duration (years), and $T_{\mathrm{a}}$ is the average time (lifetime) (days).

\section{Risk assessment}

Risk assessment provides quantitative estimation of the health risk that may occur as a result of exposure to pollutant (EPA, 2009). Risk assessment is carried out in 2 different ways which include carcinogenic and non-carcinogenic risks (EPA, 2009). The non-carcinogenic risk is defined as hazard quotient (HQ). First, the HQ value for each item is calculated, then the hazard index (HI) is determined by summing the individual HQ values (EPA, 2009; Rovira et al., 2010). Non-carcinogenic risk can be calculated according to Eq. (2) (EPA, 2009).

$\mathrm{HQ}_{\text {inh }}=\frac{\mathrm{CE}_{\mathrm{c}}}{C_{\mathrm{ref}}}$

where $\mathrm{HQ}_{\text {inh }}$ is the hazard quotient via inhalation (unitless) and $C_{\text {ref }}$ is the reference concentration ( $\mu \mathrm{g} /$ $\mathrm{m}^{3}$ ). Since reference concentrations for $\mathrm{PM}_{2,5}, \mathrm{PM}_{10}$, TVOC, and $\mathrm{CH}_{2} \mathrm{O}$ were not reported in the literature and Integrated Risk Information System (EPA, 2014), the limit values in the indoor air quality guide were used as the reference concentrations in the calculation of HQ. It was estimated whether these 4 pollutants measured in indoor air cause undesirable effects on humans. HQ of 1.0 is considered to be standard of safety. HQ that is $<1.0$ indicates a negligible risk; that is, the pollutant is not likely to induce adverse health effects. HQ $>1.0$ indicates that there may be some risks to exposed people (EPA, 1989). The lifetime cancer risk for formaldehyde was calculated according to the inhalation dosimeter method by Eq. (3). $\mathrm{CR}<1 \times 10^{-6}$ can be tolerated, $\mathrm{CR}>1 \times 10^{-4}$ is the risk value that requires action and the exposed persons should be protected (Chan et al., 2018; Lee et al., 2006). Carcinogenic risk of less than $1 \times 10^{-6}$ can be neglected according to Environmental Protection Agency (EPA, 2009).

$\mathrm{CR}_{\text {inh }}=E_{\mathrm{c}} \times \mathrm{IUR}$

where EC is the exposure concentration $\left(\mu \mathrm{g} / \mathrm{m}^{3}\right)$ and IUR is the inhalation unit risk $\left(\mathrm{m}^{3} / \mu \mathrm{g}\right)$. Inhalation unit risk (IUR) was taken as $1.3 \times 10^{-5}\left(\mu \mathrm{g} / \mathrm{m}^{3}\right)^{-1}$ for formaldehyde (EPA, 2014).

Indoor air quality indexes

In order to determine and improve the indoor air quality, indoor air quality indices have been developed around the world in recent years. Detailed information about these indexes has been reported by Wei et al. (2016). In this study, indoor air quality index was determined according to Indoor Air Quality Certification (IAQMG, 2015) and indoor environmental index (IEI) (Moschandreas \& Sofuoglu, 1999, 2004; Sofuoglu \& Moschandreas, 2003) indices.

According to the indoor air quality certification (IAQMG, 2015), the indoor air quality level is related to the threshold values reported for the parameters (Table S1). For this reason, the measurement results determined in this study were compared with the threshold values reported for IAQ parameters in the indoor air quality certification (IAQMG, 2015). IEI was calculated according to Eqs. (4)-(6).

$$
\begin{aligned}
I D I= & \frac{1}{L} \sum_{i=1}^{L} 10 \frac{\left|C A_{i, o p t}-C A_{i, o b s}\right|}{\left|C A_{i, u c l}-C A_{i, l c l}\right|} \\
I A P I= & \frac{1}{I} \sum_{i=1}^{I} \frac{1}{J} \sum_{i=1}^{J} \frac{1}{K} \sum_{i=1}^{K} 10\left[1-\frac{C_{i, j, k}^{m a x}-C_{i, j, k}^{o b s}}{C_{i, j, k}^{m a x}-C_{i, j, k}^{m i n}}\right. \\
& \left.\left(\frac{C_{i, j, j}^{d m c}-C_{i, j, k}^{o b s}}{C_{i, j, k}^{d m c}}\right)\right]
\end{aligned}
$$

$I E I=\frac{I A P I+I D I}{2}$

where the IEI index consists of the indoor discomfort index (IDI) and the indoor air pollution index (IAPI); $L, I, J$, and $K$ are the number of parameters in each category; $C A_{i, o p t}, C A_{i, o b s}, C A_{i, u c l}$, and $C A_{i, l c l}$ are the optimum, observed, upper limit, and lower limit values of temperature or relative humidity, respectively; $C_{i, j, k}{ }^{\max }, C_{i, j, k}$ obs, 
$C_{i, j, k}{ }^{\min }$, and $C_{i, j, k}{ }^{\mathrm{dmc}}$ are the maximum, observed, minimum, and limit concentrations of pollutants, respectively.

In this study, air quality was also determined according to the indoor air quality index (IAQI) and index calculated according to Eq. (7) developed by Humphreys (2005). This index was used to determine indoor air quality in university libraries in a study conducted in India (Wu et al., 2018).

$I=\sqrt{\left(M A X\left|\frac{C_{1}}{S_{1}}, \frac{C_{2}}{S_{2}}, \ldots \ldots \ldots \ldots \frac{C_{n}}{S_{n}}\right|\right)\left(\frac{1}{n} \sum_{i=1}^{n} \frac{C i}{S i}\right)}$

where $\mathrm{Ci}$ and $\mathrm{Si}$ are the concentration of measurement and standard for the same air pollutant; $n$ is the kind of measured air pollutants. $\mathrm{Ci} / \mathrm{Si}$ is called subindex. The IAQ calculated according to this index can be categorised in 5 different classes (Table S1).

\section{Results and discussion}

Variation of indoor air quality parameters by months

The changes of average values related to the measured indoor air quality parameters in the libraries were shown in Table 2. The average temperature was measured as $22{ }^{\circ} \mathrm{C}$ and in the desired range for the indoor environment.
Relative humidity rates were also changed in the range of 43-70\%; its average was 55\% and complies with the IAQ standard. The average concentrations for $\mathrm{PM}_{2.5}$ and $\mathrm{PM}_{10}$ were determined to be $25 \mu \mathrm{g} / \mathrm{m}^{3}$ and $42 \mu \mathrm{g} / \mathrm{m}^{3}$, respectively. When the mean concentrations were compared with the 24-h limit values (WHO, 2010), $\mathrm{PM}_{2.5}$ was the same as the limit value, while $\mathrm{PM}_{10}$ was lower (Table 2).

Average TVOC concentration was determined to be $466 \mu \mathrm{g} / \mathrm{m}^{3}$ in our study. It was higher than the limit value $\left(300 \mu \mathrm{g} / \mathrm{m}^{3}\right)$ in Seifert et al. (1999) but less than the limit value $\left(600 \mu \mathrm{g} / \mathrm{m}^{3}\right)$ reported by Burnett (2005). The average TVOC concentration determined in this study is close to the results reported for university libraries in Italy $\left(433 \mu \mathrm{g} / \mathrm{m}^{3}\right.$, Fantuzzi et al., 1996) and India (465 $\mu \mathrm{g} / \mathrm{m}^{3}$, Kumar et al., 2014). TVOC has been reported to be less than $600 \mu \mathrm{g} / \mathrm{m}^{3}$ in most libraries in China, $100-538 \mu \mathrm{g} / \mathrm{m}^{3}$ in Japan (Hori et al., 2013), and 18-129 ppb in India (Sahu \& Gurjar, 2019).

The frequency of indoor ventilation was thought to be effective on TVOC concentration. Ventilation ensures the discharge of pollutants from the indoor air to the outdoor air. VOC concentration may also increase with increasing temperature. Increasing indoor temperature and decreasing air exchange negatively affect indoor air quality (Zhou et al., 2017). In both libraries, it is considered that ventilation with natural methods is a disadvantage in terms of indoor air quality. Wooden

Table 2 Change of indoor air quality parameters by months

\begin{tabular}{|c|c|c|c|c|c|c|c|c|c|c|c|c|}
\hline & \multicolumn{2}{|c|}{ Temperature $\left({ }^{\circ} \mathrm{C}\right)$} & \multicolumn{2}{|c|}{ Humidity (\%) } & \multicolumn{2}{|c|}{$\mathrm{PM}_{2.5}\left(\mu \mathrm{g} / \mathrm{m}^{3}\right)$} & \multicolumn{2}{|c|}{$\mathrm{PM}_{10}\left(\mu \mathrm{g} / \mathrm{m}^{3}\right)$} & \multicolumn{2}{|c|}{ TVOC $\left(\mu \mathrm{g} / \mathrm{m}^{3}\right)$} & \multicolumn{2}{|c|}{$\mathrm{CH}_{2} \mathrm{O}\left(\mu \mathrm{g} / \mathrm{m}^{3}\right)$} \\
\hline & Libr1 & Libr 2 & Libr 1 & Libr2 & Libr1 & Libr2 & Libr1 & Libr2 & Libr1 & Libr2 & Libr1 & Libr2 \\
\hline September & 26 & NM & 61 & NM & 12 & NM & 20 & NM & 520 & NM & 30 & NM \\
\hline October & 21 & 19.7 & 63 & 70 & 25 & 21 & 40 & 37 & 640 & 800 & 27 & 34 \\
\hline November & 22 & 18.7 & 53 & 61 & 39 & 48 & 64 & 81 & 800 & 740 & 33 & 29 \\
\hline December & 21 & 18.9 & 49 & 55 & 49 & 29 & 81 & 51 & 500 & 390 & 24 & 21 \\
\hline January & 21 & 20.3 & 45 & 46 & 48 & 30 & 74 & 49 & 270 & 240 & 20 & 10 \\
\hline February & 21 & 20.5 & 43 & 46 & 15 & 8.4 & 25 & 16 & 210 & 190 & 40 & 10 \\
\hline June & 26 & NM & 59 & NM & 7 & $\mathrm{NM}$ & 11 & $\mathrm{NM}$ & 340 & $\mathrm{NM}$ & 20 & NM \\
\hline July & 27 & NM & 59 & $\mathrm{NM}$ & 7 & NM & 11 & NM & 410 & NM & 20 & NM \\
\hline August & 26 & NM & 56 & NM & 7 & NM & 11 & NM & 450 & NM & 40 & NM \\
\hline Max & 27 & 21 & 63 & 70 & 49 & 48 & 81 & 81 & 800 & 800 & 40 & 34 \\
\hline Min & 21 & 19 & 43 & 46 & 7 & 8 & 11 & 16 & 210 & 190 & 20 & 10 \\
\hline Mean & 23 & 20 & 54 & 56 & 23 & 27 & 37 & 47 & 460 & 472 & 28 & 21 \\
\hline SD & 2.7 & 0.8 & 7.2 & 10.3 & 17.7 & 14.5 & 28.5 & 23.6 & 183.3 & 282.6 & 8.1 & 10.9 \\
\hline Mean (Libr1/Libr2) & 22 & & 55 & & 25 & & 42 & & 466 & & 25 & \\
\hline
\end{tabular}

$N M$, non-measured; $S D$, standard deviation; Libr, library 
tables, libraries, and cleaning materials (Fenech et al., 2010; Sahu \& Gurjar, 2019; Sarkhosh et al., 2012) and electronic devices (Gaur et al., 2018; Lee et al., 2001; Kagi et al., 2007; Horemans et al., 2010) in libraries are considered to be the most important sources of volatile organic compounds.

Average $\mathrm{CH}_{2} \mathrm{O}$ concentration $\left(25 \mu \mathrm{g} / \mathrm{m}^{3}\right)$ was also lower than the specified limit value $\left(100 \mu \mathrm{g} / \mathrm{m}^{3}\right)$. Wooden furniture, floor coverings, cleaning agents, disinfectants, and electronic devices were considered to be the most important indoor sources of formaldehyde in the libraries. In a study conducted in different rooms of the university library in China (Beijing), the highest $\mathrm{CH}_{2} \mathrm{O}$ concentration was determined as $42 \mu \mathrm{g} / \mathrm{m}^{3}$ (Wu et al., 2018). In studies conducted in dwellings, it has been determined that the average values were $17 \mu \mathrm{g} / \mathrm{m}^{3}$ in California (Mullen et al., 2016), $31 \mu \mathrm{g} / \mathrm{m}^{3}$ in France (Dallongeville et al., 2015), $27 \mu \mathrm{g} / \mathrm{m}^{3}$ in Spain (Rovira et al., 2016), and $30-150 \mu \mathrm{g} / \mathrm{m}^{3}$ in Lisbon (Almeida-Silva et al., 2014).

\section{Variation of indoor air quality parameters by seasons}

Mann-Whitney $U$ test was applied to compare the mean values of summer and winter seasons. Since $p>0.05$ for $\mathrm{PM}_{2.5}$, TVOC, and $\mathrm{CH}_{2} \mathrm{O}$, there was no statistically significant difference between the summer/winter averages of these parameters. On the other hand, the averages of temperature, humidity, and $\mathrm{PM}_{10}$ were not equal in summer and winter seasons, and there was a statistically significant difference $(p<0.05)$ between them.

The seasonal change of the $\mathrm{PM}_{2.5}$ and $\mathrm{PM}_{10}$ concentrations determined for the winter season is approximately four times of the summer season (Fig. 1). While the $\mathrm{PM}_{2.5}$ concentration exceeded the limit value in autumn and winter seasons, $\mathrm{PM}_{10}$ was approximately at the limit value. In contrast to the summer season, the increasing PM concentration in the winter season is thought to be related to the increasing number of students and their activities. Indoor secondary blowing dust has been reported as a source of $\mathrm{PM}_{10}$ in indoor air by many researchers (Chatoutsidou et al., 2015; Szigeti et al., 2016). The determination of the lowest particulate matter concentrations in the summer months when the students are on holiday supported this idea. Another reason may be the natural ventilation method. Natural ventilation with open windows in winter causes particulate matter to leak from the outside to the indoor environment (Goyal \& Kumar, 2013; Sahu \& Gurjar, 2019). In addition, higher infiltration rate from outdoor air to indoor air causes higher $\mathrm{PM}_{2.5}$ concentrations in winter season (Su et al., 2015; Wu et al., 2018). The data obtained from the National Air Quality Monitoring System of the Ministry of Environment, Urbanization and Climate Change of the Republic of Turkey (https://www.havaizleme.gov.tr/) confirms this estimation. Outdoor concentrations of $\mathrm{PM}_{10}$ and $\mathrm{PM}_{2.5}$ were determined to be $73 \mu \mathrm{g} / \mathrm{m}^{3}$ and $43 \mu \mathrm{g} / \mathrm{m}^{3}$ in winter and $26 \mu \mathrm{g} / \mathrm{m}^{3}$ and $13 \mu \mathrm{g} / \mathrm{m}^{3}$ in summer seasons, respectively.

Contrary to particulate matter concentrations, TVOC and $\mathrm{CH}_{2} \mathrm{O}$ concentrations were found higher in summer (Fig. 1). TVOC concentrations are affected by temperature, humidity, and ventilation frequency (Chi et al., 2016; Gao et al., 2012; Lim et al., 2014; Tao et al., 2015; Wu et al., 2018). In this study, TVOC concentration was found to be $300 \mu \mathrm{g} / \mathrm{m}^{3}$ in winter $\left(T=20{ }^{\circ} \mathrm{C}\right.$, $\mathrm{H}=47 \%)$ and $400 \mu \mathrm{g} / \mathrm{m}^{3}$ in summer $\left(T=26{ }^{\circ} \mathrm{C}\right.$, $H=58 \%$ ). It is thought that increasing temperature values increase the concentration of VOC released from indoor sources (furniture, building materials, etc.). Especially VOCs with high boiling points such as alkanes are detected more in summer when the average temperature is higher than in winter (Lin et al., 2009).

A similar trend has been detected for formaldehyde. $\mathrm{CH}_{2} \mathrm{O}$ concentration was determined to be $21 \mu \mathrm{g} / \mathrm{m}^{3}$ in winter $\left(T=20{ }^{\circ} \mathrm{C}, H=48 \%\right)$ and $27 \mu \mathrm{g} / \mathrm{m}^{3}$ in summer $\left(T=27{ }^{\circ} \mathrm{C}, H=58 \%\right.$ ) (Fig. 1). In a study conducted in 602 dwellings in Japan, it was reported that the average $\mathrm{CH}_{2} \mathrm{O}$ concentration was $13 \mu \mathrm{g} / \mathrm{m}^{3}$ in winter (mean temperature $17{ }^{\circ} \mathrm{C}$, mean relative humidity $48 \%$ ) and $34 \mu \mathrm{g} / \mathrm{m}^{3}$ in summer (mean temperature $28{ }^{\circ} \mathrm{C}$ and mean relative humidity 63\%) (Uchiyama et al., 2015). Cheng et al. (2017) reported higher formaldehyde concentrations in summer in large departments. A striking point in this study was that TVOC concentrations were high in both libraries during the autumn season. Concentration increase was thought to be related to other factors (outdoor air infiltration ratio, outdoor anthropogenic sources, etc.) as indoor sources did not change. Since autumn is a transition season, the temperature difference between indoor and outdoor environments is lower in this season than in winter (Wallace et al., 2002; Wu et al., 2018). This situation causes the infiltration rate to be 2-3 times lower in the transition season compared to the winter season and, therefore, the indoor air quality in the transition seasons is lower 
Fig. 1 Change of indoor air quality parameters by certain seasons

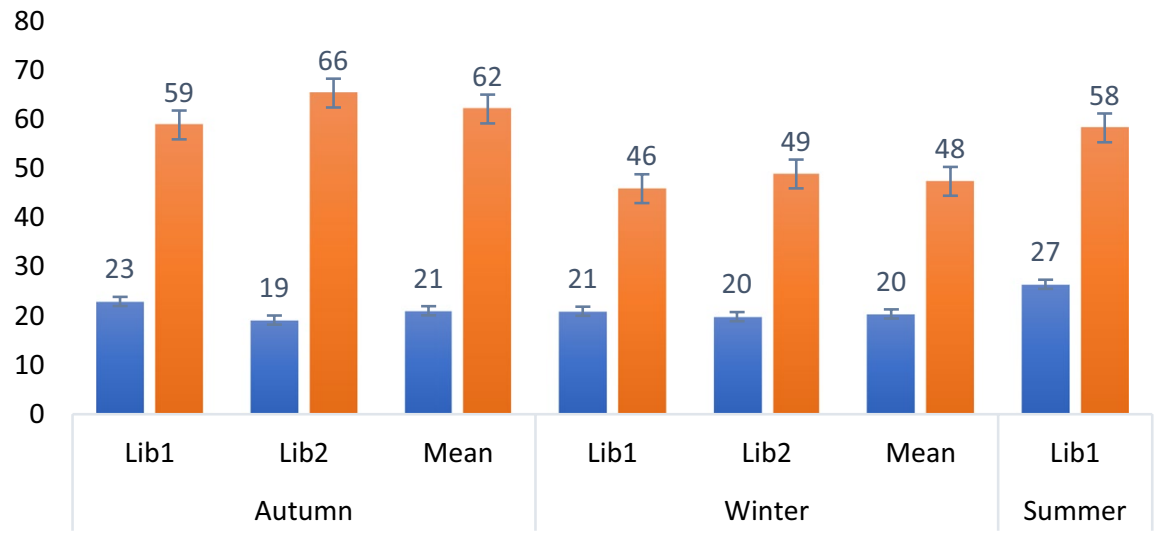

- Temperature $\left({ }^{\circ} \mathrm{C}\right) \square$ Humidity (\%)

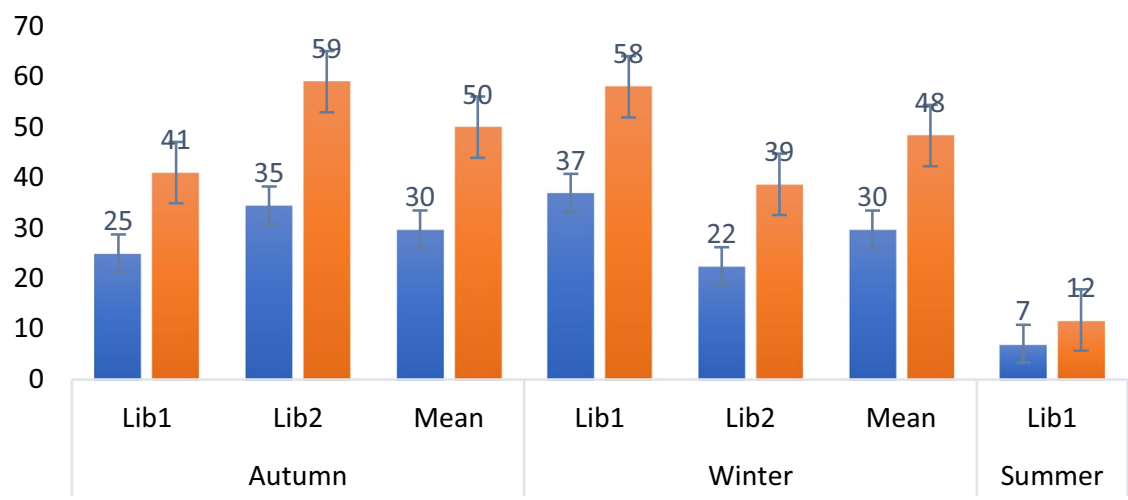

— PM2.5 $(\mu \mathrm{g} / \mathrm{m} 3) \quad \mathrm{PM} 10(\mu \mathrm{g} / \mathrm{m} 3)$

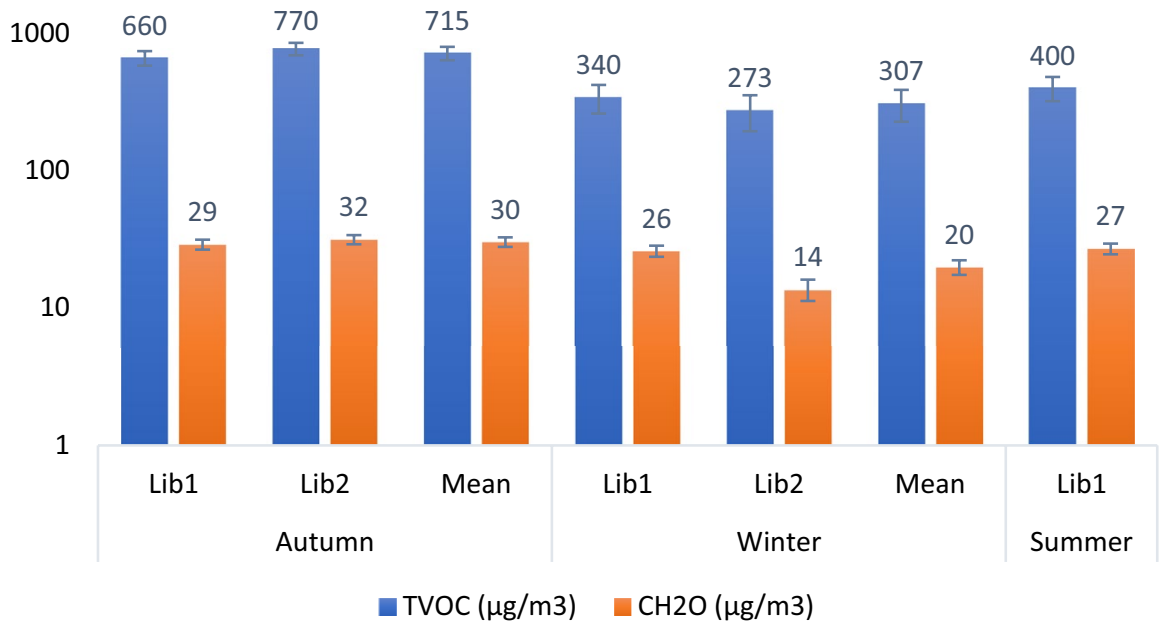

(Wallace et al., 2002; Wu et al., 2018). In our study, determining a similar trend for libraries in two different locations in autumn supported this idea. Another reason may be anthropogenic activities in the outdoor environment. Both libraries are located close to the village settlement. Agricultural waste combustion, which is common in villages especially in autumn, is thought to cause an increase in indoor TVOC and formaldehyde 
concentrations. Toluene, benzene, methylene chloride, propylene-n-hexane, n-heptane, glyoxal, acrolein, and freon-11 are compounds highly associated with vehicle emissions, biomass combustion, industrial emissions, and solvent use (Li et al., 2017; Xue et al., 2017; Zhang et al., 2012). Also, the increase in vehicle traffic around the campus in autumn was considered another possible reason. In another study, it was reported that carbonyl emissions in microenvironments close to high-traffic streets were $10 \%$ higher than in points far from traffic (Chan et al., 2018; Ho et al., 2012; Morknoy et al., 2011). As a result, apart from the anthropogenic activities in the outdoor environment, the difference in meteorological parameters and the indoor air change rate also affect the indoor air quality (Chan et al., 2018).

Variation of indoor air quality parameters by morning and afternoon

There was no significant change between the morning and afternoon values of the parameters (Figs. 2 and 3). Insignificant increase was determined for temperature, humidity, and TVOC values in the afternoon unlike $\mathrm{PM}_{2.5}$ and $\mathrm{PM}_{10}$ concentrations. TVOC values were higher in the morning hours in the summer while higher in the afternoon in the winter. This situation can be explained by natural ventilation in libraries. High temperatures and lack of ventilation during the summer season may be resulted in increased VOC emissions during the night and high concentration in the morning hours. Similarly, Gaur et al. (2018) reported higher TVOC concentrations in the morning hours. More ventilation during the day in the summer is thought to result in a decrease in TVOC concentrations in the afternoon. Wiglusz et al. (2002) reported that the indoor VOC concentration decreases as ventilation increases. For the winter season, the opposite trend has been determined. In the winter season, lower concentrations were determined in the morning hours unlike afternoon. It is thought that the TVOC concentration decreased in the morning hours as both the temperature decreased during the night and there was no human activity. In the afternoon, it is thought that the VOC concentration increased due to the increasing temperature, the number of people, cleaning work, use of deodorant and room perfume, and decreased ventilation frequency (due to the need for heating). As it is known, as the ventilation rate increases, the VOC concentrations in the indoor environment decrease (Wiglusz et al., 2002). In conclusion, in this study, it was determined that temperature and indoor air change rate directly affect TVOC concentrations in winter and summer seasons. The same situation was determined for formaldehyde. For this reason, the explanations made for TVOC are also valid for formaldehyde.

Particulate matter concentrations were higher in the morning hours. This situation can be explained by the greater physical activity between morning and noon and the resuspension of the dusts to indoor air (blowing dust) as explained earlier. Gaur et al. (2018) reported that the concentration of particulate matter was higher in the morning hours when the library was crowded. In addition, natural ventilation in the morning hours may cause outdoor particulate matter to leak from the outdoor air to the indoor air. As explained in the previous section, infiltration from outdoor air to indoor air is higher in naturally ventilated microenvironments compared to mechanically ventilated microenvironments (Dockery \& Spengler,
Fig. 2 Changes of temperature $\left({ }^{\circ} \mathrm{C}\right)$ and humidity $(\%)$ in the morning and afternoon

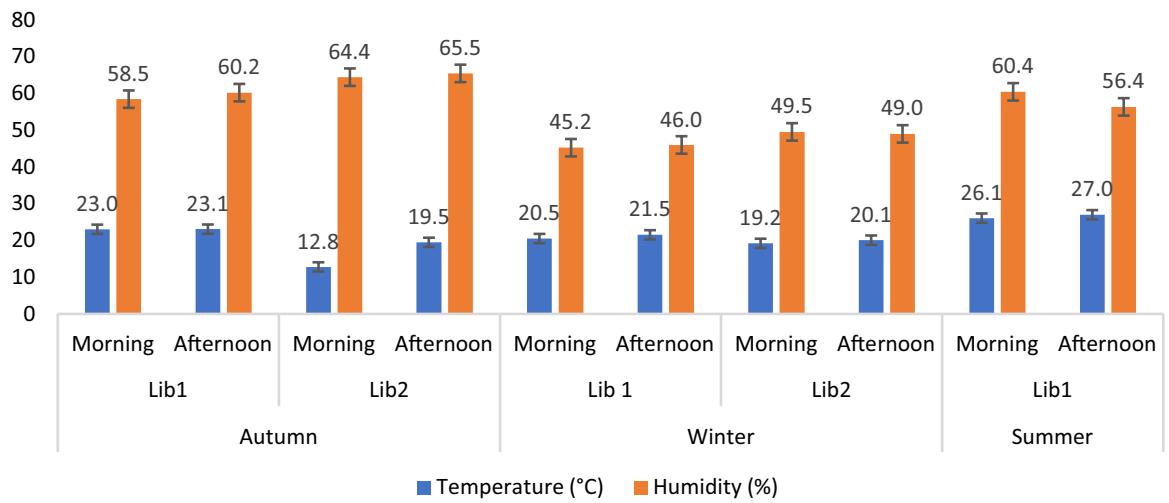

Springer 

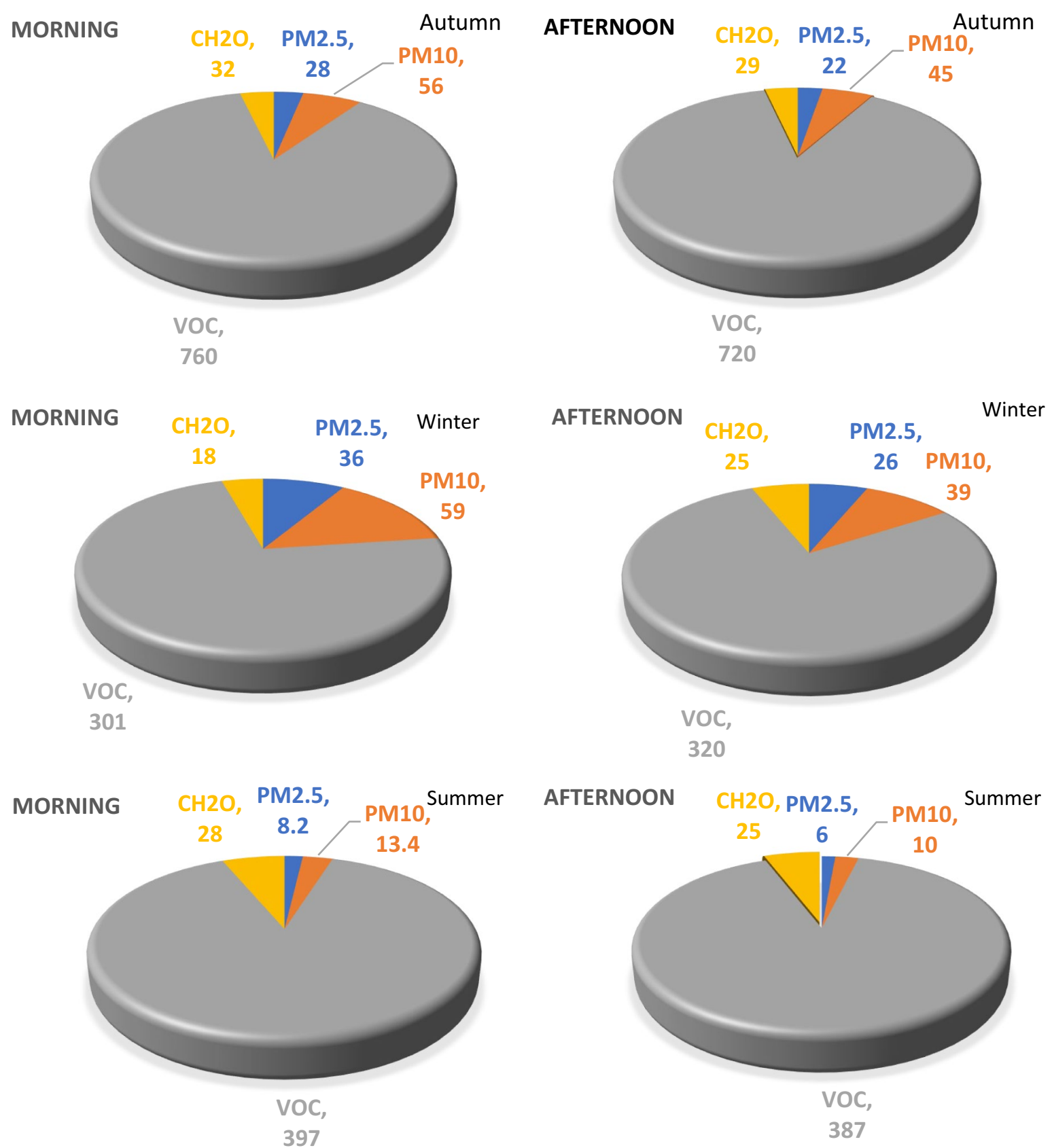

Fig. 3 Changes of formaldehyde, TVOC, and PM $\left(\mu \mathrm{g} / \mathrm{m}^{3}\right)$ in the morning and afternoon

1981; Goyal \& Kumar, 2013; Sahu \& Gurjar, 2019; Taylor et al., 2014). For this reason, it is thought that the infiltration rate was higher and more particulate matter leaked into the indoor environment due to the greater temperature difference between indoor and outdoor environments in winter.
Variation of indoor air quality according to different rooms of the libraries

One of the aims of this study is to determine the relationship between the age of the building and the TVOC and $\mathrm{CH}_{2} \mathrm{O}$ concentrations that may occur from building 
materials and to determine the air quality in different parts of the libraries. The building age of Libr 1 is $>30$ years, and Libr 2 is a building of about 5 years. When the indoor quality parameters of both libraries were compared, no significant difference could be determined between the parameters. Independent samples $t$-test was applied to compare the mean values determined for Lib1/Lib2. Since $p>0.05$ for all parameters except temperature, it was determined that there was no statistically significant difference between the averages of both libraries. Measurement could not be made in Libr 2 because it was closed in summer (Fig. 1). For this reason, the average temperature for Libr 1 was determined to be higher. In addition, the average temperatures in Libr 1 for the autumn and winter seasons were measured higher than Libr 2. This situation can be explained by the fact that Libr 2 is located in the basement and is less affected by sunlight. No significant difference was found for autumn and winter when TVOC and $\mathrm{CH}_{2} \mathrm{O}$ concentrations were compared to assess $\mathrm{VOC}$ and $\mathrm{CH}_{2} \mathrm{O}$ concentrations that could be released from building materials. For this reason, it is considered that building materials did not significant affect VOC and $\mathrm{CH}_{2} \mathrm{O}$ concentrations in a 5 -year-old building. Considering the total TVOC concentration, there was no significant difference between Libr $1\left(460 \mu \mathrm{g} / \mathrm{m}^{3}\right)$ and Libr $2\left(472 \mu \mathrm{g} / \mathrm{m}^{3}\right)$. The average $\mathrm{CH}_{2} \mathrm{O}$ concentration was determined to be $25 \mu \mathrm{g} /$ $\mathrm{m}^{3}$. When Libr 1 and Libr 2 are compared in terms of indoor resources, it has been determined that the number of computers is higher in Libr 1, the bookshelf are wooden, and PVC and wooden materials are used in the floor covering. In Libr 2, holding books are made of metal material and the ground is covered with stone. It is also thought that cooking activities originating from the student canteen were also effective in Libr 2.

The change of indoor quality parameters according to different parts of the libraries is shown in Table S2. Temperature and humidity did not change significantly. $\mathrm{PM}_{2.5}$ and $\mathrm{PM}_{10}$ concentrations in Libr 1 were higher in the entrance section compared to the other section. In this section, it is thought that higher human activity and continuous opening and closing of the entrance door were important in the resuspension of dust (especially $\mathrm{PM}_{10}$ ). The highest particulate matter concentration in Libr 2 was determined in the reading room with the highest activity. This section is completely separate from the other sections, and human activities are more here.
TVOC concentration varied between rooms in both libraries. In Libr 2, the lowest concentration entrance and the highest concentration were determined in the bookshelf. The lowest concentration in Libr 1 was determined in the bookshelf and reading section. The highest concentration was determined in the entrance section in Lib 1. This can be explained by the use of hand sanitizer or other personal disinfectant products in the entrance area, especially during the summer sampling, within the scope of COVID 19 measures. $\mathrm{CH}_{2} \mathrm{O}$ concentration was also determined at slightly higher concentration in compartments with computers. The determination of the highest $\mathrm{CH}_{2} \mathrm{O}$ concentration in Libr 2 in the entrance section can be explained by the computers and book browsers. In addition, it is thought that the cooking emissions (Huang et al., 2011; Svendsen et al., 2002) coming from the student canteen located on the side of the Libr 2 were effective in the formaldehyde concentration.

Evaluation of human health risks

In this study, chronic exposure concentrations were calculated for library staff and students, and then, carcinogenic and non-carcinogenic risk analysis was performed. Chronic exposure concentration (CEc) was calculated for library staff and students using the values shown in Table 3 . Since IUR values were not available, only non-carcinogenic risks were calculated for $\mathrm{PM}_{2.5}, \mathrm{PM}_{10}$, and TVOC. Since the carcinogenicity of $\mathrm{CH}_{2} \mathrm{O}$ was defined by EPA (2014), the carcinogenic risk for $\mathrm{CH}_{2} \mathrm{O}$ was also calculated. $\mathrm{EC}_{\text {inh }}$ values determined for library staff were found higher than students (Table 4). The highest exposure concentration was determined for TVOC depending on the ambient air concentrations (Table 4). Since there is no reference concentration value defined in the literature for these parameters, the limit values reported in the indoor quality guide were used as reference concentrations. Therefore, the $\mathrm{HQ}_{\mathrm{S}}$ were calculated to

Table 3 Exposure frequency, exposure duration, and averaging time for different exposure groups

\begin{tabular}{llll}
\hline Exposed group & $\begin{array}{l}\text { Exposure } \\
\text { frequency (EF) } \\
\text { (days/year) }\end{array}$ & $\begin{array}{l}\text { Exposure } \\
\text { duration (ED) } \\
\text { (year) }\end{array}$ & $\begin{array}{l}\text { Average } \\
\text { time (AT) } \\
\text { (days) }\end{array}$ \\
\hline Library staff & 260 & 30 & 7800 \\
Student & 88 & 4 & 352 \\
\hline
\end{tabular}


Table 4 Chronic exposure concentration $\left(\mathrm{CE}_{\mathrm{C}}\right)$, non-carcinogenic (HQ), and carcinogenic risk (CRinh) values

\begin{tabular}{|c|c|c|c|c|c|c|c|c|}
\hline & \multicolumn{2}{|l|}{ Libr 1} & \multicolumn{2}{|l|}{ Libr 2} & \multicolumn{2}{|l|}{ Libr 1} & \multicolumn{2}{|l|}{ Libr 2} \\
\hline & \multicolumn{4}{|l|}{ Library staff } & \multicolumn{4}{|l|}{ Student } \\
\hline & $\overline{\mathrm{CE}}$ Cinh $\left(\mu \mathrm{g} / \mathrm{m}^{3}\right)$ & $\mathrm{HQ}$ & $\mathrm{CE}_{\mathrm{Cinh}}\left(\mu \mathrm{g} / \mathrm{m}^{3}\right)$ & $\overline{\mathrm{HQ}}$ & $\overline{\mathrm{CE}_{\text {Cinh }}\left(\mu \mathrm{g} / \mathrm{m}^{3}\right)}$ & $\mathrm{HQ}$ & $\mathrm{CE}_{\text {Cinh }}\left(\mu \mathrm{g} / \mathrm{m}^{3}\right)$ & $\mathrm{HQ}$ \\
\hline \multicolumn{9}{|c|}{ Non-carcinogenic risk $(\mathrm{HI})$} \\
\hline $\mathrm{PM}_{2.5} \mu \mathrm{g} / \mathrm{m}^{3}$ & 7.7 & 0.31 & 9.1 & 0.36 & 1.92 & 0.08 & 2.3 & 0.09 \\
\hline $\mathrm{PM}_{10} \mu \mathrm{g} / \mathrm{m}^{3}$ & 12.2 & 0.24 & 15.6 & 0.31 & 3.06 & 0.06 & 3.9 & 0.08 \\
\hline TVOC $\mu \mathrm{g} / \mathrm{m}^{3}$ & 156.2 & 0.27 & 157.3 & 0.26 & 39.05 & 0.07 & 39.3 & 0.07 \\
\hline $\mathrm{CH}_{2} \mathrm{O} \mu \mathrm{g} / \mathrm{m}^{3}$ & 9.1 & 0.09 & 6.9 & 0.07 & 2.28 & 0.02 & 1.73 & 0.02 \\
\hline HI ( $\sum$ HQ) & & 0.91 & & 1.00 & & 0.23 & & 0.25 \\
\hline \multicolumn{9}{|c|}{ Lifetime cancer risk $\left(\mathbf{C R}_{\text {inh }}\right)$} \\
\hline $\mathrm{CH}_{2} \mathrm{O}$ & $1.20 \mathrm{E}-04$ & & $9.01 \mathrm{E}-05$ & & $2.97 \mathrm{E}-05$ & & $2.25 \mathrm{E}-05$ & \\
\hline
\end{tabular}

estimate the deleterious effect, although they do not directly reflect toxicity. Since the calculated HQ and HI for both exposure groups were $\leq 1$, the pollutants did not pose any danger to human health (Table 4). Consequently, more ventilation is required in both libraries to reduce the exposure to $\mathrm{CH}_{2} \mathrm{O}$ and TVOC compounds.

Lifetime cancer risk for formaldehyde was calculated for staff and students (Table 4). The carcinogenic risk determined for both groups was higher than the limit value $\left(1 \times 10^{-6}\right)$ determined by the EPA (2009). Nevertheless, the risk value calculated for personnel in Libr 1 slightly exceeded the value $\left(1 \times 10^{-4}\right)$ (Chan et al., 2018; Lee et al., 2006) reported as the action level of the exposed persons to be protected. The highest $\mathrm{CH}_{2} \mathrm{O}$ concentrations in Libr 1 were determined in February and August months. During the February sampling, it was determined that the odour of household cleaners or room perfume was prominent in the indoor environment in Libr 1. As explained in the previous sections, less ventilation frequency in winter may be result in higher $\mathrm{CH}_{2} \mathrm{O}$ concentration indoors. It is thought that hand disinfectants and cleaning agents used extensively during the summer period within the scope of the COVID 19 pandemic measure cause an increase in $\mathrm{CH}_{2} \mathrm{O}$ concentrations.

Carcinogenic risk caused by formaldehyde has been reported in many studies in the literature. For example, it has been reported in the ranges of $49-61 \times 10^{-5}$ for dwellings and 34-130 $\times 10^{-5}$ for office in Mexico (Baez et al., 2003), 0.6-2.3 $\times 10^{-5}$ for office in Brazil (Cavalcante et al., 2006), and 4.3-9.9 $\times 10^{-5}$ for dwellings in Sri Lanka (Chan et al., 2018).

\section{Determination of indoor air quality index}

IAQ level for both libraries was determined according to IEI, IAQC, and IAQI indexes. When the calculation was made according to the limit values reported in Table 1, the IEI score was determined as 9.5 and 8.4 for Libr 1 and Libr 2, respectively. When calculating according to the threshold values shown for each parameter in Table S1, the IEI score was determined as 10.8 and 9.43 for Libr 1 and Libr 2, respectively. As a result, according to the calculated IEI scores, it was determined that the indoor air quality of the libraries was bad. According to the IAQI proposed by Humphreys, the score was determined as 1.09 for Libr 1 and 1.07 for Libr 2. According to this index, it was determined that the indoor air of the libraries was slightly polluted. In addition, according to this index, it has been determined that the sub-index $(\mathrm{Ci} / \mathrm{Si})$ value of TVOC is the highest. On the other hand, when the results determined in this study were compared with the limit values reported by IAQC (Table S1), it was determined that the indoor air quality of the libraries was good in terms of all parameters. As a result, quality indexes are not consistent with each other. Similarly, Wei et al. (2016) reported that the index results were not consistent in their study related to the indoor air quality indexes.

\section{Conclusions}

As a result, it was determined that the mean concentration of TVOC exceeded the limit value reported by Seifert et al. (1999) in both libraries. It was determined 
that the building age (Libr 1>30, Libr $2 \approx 5$ ) was not effective on gas phase pollutants in both libraries whose ventilation and heating methods were the same and the indoor pollutant sources were very similar. Pollutant concentrations varied seasonally. Those in gas phase were higher in summer while those in particulate phase were higher in winter. As a result of natural ventilation through open windows in winter, PM leaks from the external environment to the indoor environment. In addition, the increasing student population was thought to cause an increase in PM concentrations in winter. In autumn, which is the transition season, it was determined that the indoor air quality was worse in both libraries. Therefore, depending on the indoor/ outdoor air exchange rate, meteorological parameters, and anthropogenic sources in the outdoor environment, it is thought that the natural ventilation method affects the indoor air quality positively or negatively. Pollutant concentrations were found to vary both seasonally and during the day (morning and afternoon).

The results showed that seasonal and daily changes were associated with meteorological factors, indoor temperature and humidity values, ventilation frequency, human activity, and the type and density of anthropogenic sources in the outdoor environment. Since the HQ and HI values were computed as $\leq 1$, the pollutants did not pose any danger to humans (noncarcinogenic). However, the lifetime cancer risk value calculated for formaldehyde was higher than the limit value $\left(1 \times 10^{-6}\right)$ reported by the EPA (2009). As a result, according to the results obtained from this study, it is thought that the indoor air quality of the libraries is affected by many parameters related to both indoor and outdoor environments (due to natural ventilation). Therefore, it is thought that mechanical ventilation will be more effective for better indoor quality.

Funding This research was funded by Bartin University Scientific Research Projects Coordination Unit (Project No.: 2019-FEN-A-018).

Data availability All data generated or analysed during this study are included in this published article (and its supplementary information files).

Code availability Not applicable.

\section{Declarations}

Ethics approval Not applicable.
Consent to participate Not applicable.

Consent for publication Not applicable.

Conflict of interest The authors declare no competing interests.

\section{References}

Almeida-Silva, M., Wolterbeek, H. T., \& Almeida, S. M. (2014). Elderly exposure to indoor air pollutants. Atmospheric Environment, 85, 54-63.

Ashford, N. A., \& Caldart, C. C. (2001). Negotiated environmental and occupational health and safety agreements in the United States: Lessons for policy. Journal of Cleaner Production, 2, 99-120.

ASHRAE. (2004). Standard 55-2004, thermal environmental conditions for human occupancy, Atlanta, 7 pages.

Baccioglu, A., \& Kalpaklioglu, A. F. (2007). An unusual form of formaldehyde induced lung disease. Allergologia et Immunopathologia - Journal, 35, 110-2.

Baez, A., Padilla, H., Garcia, R., Torres Mdel, C., Rosas, I., \& Belmont, R. (2003). Carbonyl levels in indoor and outdoor air in Mexico City and Xalapa, Mexico. Science of the Total Environment, 302, 211-226.

Bakian, A. V., Huber, R. S., Coon, H., et al. (2015). Acute air pollution exposure and risk of suicide completion. American Journal of Epidemiology, 181, 295-303.

Boeglin, M. L., Wessels, D., \& Henshel, D. (2006). An investigation of the relationship between air emissions of volatile organic compounds and the incidence of cancer in Indiana counties. Environmental Research, 2, 242-254.

$\mathrm{Bu}, \mathrm{Z}$., Zhang, Y., Mmereki, D., et al. (2016). Indoor phthalate concentration in residential apartments in Chongqing, China: Implications for preschool children's exposure and risk assessment. Environmental Science and Pollution Research, 127, 34-45.

Burnett, J. (2005). Indoor air quality certification scheme for Hong Kong buildings. Indoor and Built Environment, 14(34), 201-208. https://doi.org/10.1177/1420326X05053788

Cavalcante, R. M., Campelo, C. S., Barbosa, M. J., Silveira, E. R., Carvalho, T. V., \& Nascimento, R. F. (2006). Determination of carbonyl compounds in air and cancer risk assessment in an academic institute in Fortaleza. Brazil. Atmospheric Environment., 40, 5701-5711.

Chan, C. S., Ranasinghe, R. S. S., Ho, S. S. H., Ho, K. F., Yim, S. H. L., Sugathapala, A. G. T., Lee, S. C., Hungh, W. T., Huang, Y., \& Zhang, H. (2018). Evaluation of hazardous airborne carbonyls in five urban roadside dwellings: A comprehensive indoor air assessment in Sri Lanka. Atmospheric Pollution Research, 9, 270-277.

Chatoutsidou, S. E., Ondráček, J., Tesar, O., Tørseth, K., Ždímal, V., \& Lazaridis, M. (2015). Indoor/outdoor particulate matter number and mass concentration in modern offices. Building and Environment, 92, 462-474.

Cheng, L., Li, B., Cheng, Q., et al. (2017). Investigations of indoor air quality of large department store buildings in 
China based on field measurements. Building and Environment, 118, 128-143.

Chi, C., Chen, W., Guo, M., et al. (2016). Law and features of TVOC and formaldehyde pollution in urban indoor air. Atmospheric Environment, 132, 85-90.

Dallongeville, A., Costet, N., Zmirou-Navier, D., Le Bot, B., Chevrier, C., Deguen, S., Annesi-Maesano, I., \& Blanchard, O. (2015). Volatile and semi-volatile organic compounds of respiratory health relevance in French dwellings. Indoor Air, 26, 426-438.

Dockery, D. W., \& Spengler, J. D. (1981). Indoor-outdoor relationships of respirable sulfates and particles. Atmospheric Environment, 15, 335-343. https://doi.org/10.1016/00046981(81)90036-6

Eigurenfernandez, A., Shinyashiki, M., Schmitz, D. A., et al. (2010). Redox and electrophilic properties of vapor-and particle-phase components of ambient aerosols. Environmental Research, 110, 207-212.

EPA. (1989). Risk assessment guidance for superfund, Vol 1: Human health evaluation manual (Part A), 1989. http:// www.epa.gov/superfund/programs/risk/ragsa/

EPA. (2009). Risk Assessment Guidance for Superfund Volume I: Human Health Evaluation Manual (Part F, Supplemental Guidance for Inhalation Risk Assessment). EPA540-R-070-002United States Environmental Protection Agency, Washington DC, USA.

EPA. (2014). Integrated Risk Information System (IRIS). U.S. Environmental Protection Agency Chemical Assessment Summary. Formaldehyde; CASRN 50-00-0 https://cfpub.epa.gov/ncea/iris2/chemicallanding.cfm? substance_nmbr=419.

EPA. (2020a). Available: epa.gov/indoor-air-quality-iaq/ volatile-organic-compounds-impact-indoor-air-quality.

EPA. (2020b). Available: https://www.epa.gov/indoor-airquality-iaq/indoor-particulate-matter

Fantuzzi, G., Aggazzotti, G., Righi, E., Cavazzuti, L., Predieri, G., \& Franceschelli, A. (1996). Indoor air quality in the university libraries of Modena (Italy). Science of the Total Environment, 193, 49-56.

Fenech, A., Strlic, M., Kral, j., Cigic, I., et al. (2010). Volatile aldehydes in libraries and archives. Atmospheric Environment, 44, 2067-2073.

Gao, J.M., Chen, L., Zhang, Y., et al. (2012). Occurrence and pollution source of TVOC in underground stores in Chongqing. Journal of Central South University(Science and Technology), 43, 4554-8.

Gaur, M., Bhandari, K., \& Shukla, A. (2018). Monitoring of total volatile organic compounds and particulate matter in an indoor environment. Current Science, 115, 1787-1792.

Goyal, R., \& Kumar, P. (2013). Indoor-outdoor concentrations of particulate matter in nine microenvironments of a mix-use commercial building in megacity Delhi. Air Quality, Atmosphere \& Health, 6, 747-757. https://doi. org/10.1007/s11869-013-0212-0

Gunes, G., Bozkurt, E., Sönmez, S., \& Cakir, N. (2015). An investigation of the indoor air quality in libraries: Marmara University Central Library. World of Knowledge, 16, 222-241.

HC (Health Canada). (1995). Exposure guidelines for residential indoor air quality: A report of the federal-provincial advisory committee on environmental and occupational health, Ottawa, 29 pages.

Hizrri, A., Khadijah, H., Noor Faizul Hadry, N., Norhidayah, A., \& Mohd Shukri, M.A. (2015). Indoor microbial contamination and its relation to physical indoor air quality characteristics at selected libraries in Pahang. Advancement in Environmental, Agricultural and Plant Biotechnology, 77, 51-56. https://doi.org/10.11113/jt.v77.6707

Ho, S. S. H., Ho, K. F., Lee, S. C., Cheng, Y., Yu, J. Z., Lam, K. M., Feng, N. S. Y., \& Huang, Y. (2012). Carbonyl emissions from vehicular exhausts sources in Hong Kong. Journal of the Air \& Waste Management Association, 62, 221-234.

Horemans, B., \& Van Grieken, R. (2010). Speciation and diurnal variation of thoracic, fine thoracic and sub-micrometer airborne particulate matter at naturally ventilated office environments. Atmospheric Environment, 44, 1497-1505.

Hori, H., Ishimatsu, S., Fueta, Y., \& Ishidao, T. (2013). Evaluation of a real-time method for monitoring volatile organic compounds in indoor air in a Japanese university. Environmental Health and Preventive Medicine, 18, 285292. https://doi.org/10.1007/s12199-012-0319-1, https:// doi.org/10.1016/j.atmosenv.2013.11.061

Huang, Y., Ho, S. S. H., Ho, K. F., Lee, S. C., Yu, J. Z., \& Louie, P. K. K. (2011). Characteristics and health impacts of VOCs and carbonyls associated with residential cooking activities in Hong Kong. Journal of Hazardous Materials, 186, 344-351.

Hulin, M., Simoni, M., Viegi, G., et al. (2012). Respiratory health and indoor air pollutants based on quantitative exposure assessments. European Respiratory Journal, 40, 1033-1045.

Humphreys, M. (2005). Quantifying occupant comfort: Are combined indices of the indoor environment practicable. Building Research \& Information, 33, 317-325.

IAQMG (Indoor Air Quality Management Group). (2015). A Guide on Indoor Air Quality Certification Scheme for Offices and Public Places. http://www.iaq.gov.hk/en/publications-andreferences/guidance-notes.aspx (Accessed 9 November 15).

Kagi, N., Fujii, S., Horiba, Y., Namiki, N., Ohtani, Y., Emi, H., et al. (2007). Indoor air quality for chemical and ultrafine particle contaminants from printers. Building and Environment, 42, 1949-1954.

Kelly, F. J., \& Fussell, J. C. (2011). Air pollution and airway disease. Clinical \& Experimental Allergy, 41, 1059-1071.

Klinmalee, A., Srimongkol, K., \& Oanh, N. T. K. (2009). Indoor air pollution levels in public buildings in Thailand and exposure assessment. Environmental Monitoring and Assessment, 156, 581-594.

Kumar, A., Singh, B. P., Punia, M., Singh, D., Kumar, K., \& Jain, V. K. (2014). Assessment of indoor air concentrations of VOCs and their associated health risks in the library of Jawaharlal Nehru University, New Delhi. Environmental Science and Pollution Research, 21, 22402248. https://doi.org/10.1007/s11356-013-2150-7

Lee, C. W., Dai, Y. T., Chien, C. H., \& Hsu, D. J. (2006). Characteristics and health impacts of volatile organic compounds in photocopy centers. Environmental Research, 100, 139-149.

Lee, S. C., Lam, S., \& Fai, H. K. (2001). Characterization of VOCs, ozone, and PM 10 emissions from office 
equipment in an environmental chamber. Building and Environment, 36, 837-842.

Li, H. X., Qin, Y. H., \& Feng, G. H. (2017). The analysis of $\mathrm{PM}_{2.5}$ university libraries reading room in winter of North China. Procedia Engineering, 205, 3346-3352.

Lim, J., Kim, S., Kim, A., et al. (2014). Behavior of VOCs and carbonyl compounds emission from different types of wallpapers in Korea. International Journal of Environmental Research and Public Health, 11, 4326-4339.

Lin, C. C., Yu, K. P., Zhao, P., et al. (2009). Evaluation of impact factors on VOC emissions and concentrations from wooden flooring based on chamber tests. Building and Environment, 44, 525-533.

Martins, P. C., Valente, J., Papoila, Al., et al. (2012). Airways changes related to air pollution exposure in wheezing children. European Respiratory Journal, 39, 246-253.

Morknoy, D., Khummongkol, P., \& Prueaksasit, T. (2011). Seasonal and diurnal concentrations of ambient formaldehyde and acetaldehyde in Bangkok. Water Air Soil Pollution, 216, 693-702.

Moschandreas, D. J., \& Sofuoglu, S. C. (2004). The indoor environmental index and its relationship with symptoms of office building occupants. Journal of the Air \& Waste Management Association, 54, 1440-1451.

Moschandreas, D., \& Sofuoglu, S. C. (1999). The indoor air pollution index, Edinburgh, Scotland. Indoor Air, 99, 261-266.

Mullen, N. A., Li, J., Russell, M. L., Spears, M., Less, B. D., \& Singer, B. C. (2016). Results of the California Healthy Homes Indoor Air Quality Study of 2011-2013: Impact of natural gas appliances on air pollutant concentrations. Indoor Air, 26, 231-245. https://doi.org/10.1111/ina.12190

Nielsen, G. D., Larsen, S. T., \& Wolkoff, P. (2017). Re-evaluation of the WHO, (2010) formaldehyde indoor air quality guideline for cancer risk assessment. Archives of Toxicology, 91, 35-61.

Republic of Turkey Ministry of Environment, Urbanization and climate change. National air quality monitoring system. Retrieved December 24, 2021, from https://www.havaizleme.gov.tr

Rovira, J., Mari, M., Nadal, M., Schuhmacher, M., \& Domingo, J. L. (2010). Environmental monitoring of metals, PCDD/Fs and PCBs as a complementary tool of biological surveillance to assess human health risks. Chemosphere, 80, 1183-1189.

Rovira, J., Roig, N., Nadal, M., Schuhmacher, M., \& Domingo, J. L. (2016). Human health risks of formaldehyde indoor levels: An issue of concern. Journal of Environmental Science and Health, Part A, 51, 357-363. https://doi.org/10. 1080/10934529.2015.1109411

Sahu, V., \& Gurjar, B. R. (2019). Spatio-temporal variations of indoor air quality in a university library. International Journal of Environmental Health Research, 28, 1-16.

Sarkhosh, M., Mahvi, A. H., Zare, M. R., Fakhri, Y., \& Shamsolahi, H. R. (2012). Indoor contaminants from hardcopy devices characteristics of VOCs in photocopy centers. Atmospheric Environment, 63, 307-312. https://doi.org/10.1016/j.atmosenv. 2012.09.058

Schäfer, I. (2014). New standards in preventive conservation management, IFLA 2014. Available: http://library.ifla.org/1005/7/ 209-schafer-en.pdf

Seifert, B., Englert, N., Sagunski, H., \& Witten, J. (1999). Guideline values for indoor air pollutants. in: Proceedings of the 8th International Conference on Indoor Air Quality and Climate, Indoor Air'99, August pp. 8-13.

Sofuoglu, S. C., \& Moschandreas, D. J. (2003). The link between symptoms of office building occupants and inoffice air pollution: The indoor air pollution index. Indoor Air, 13, 332-343.

Su, Y., Tao, J., Wang, M., et al. (2015). Surveillance for fine particles concentration in air in Shijingshan district of Beijing. J. Dis. Surveill, 30, 672-678.

Svendsen, K., Jensen, H. N., Sivertsen, I., \& Sjaastad, K. (2002). Exposure to cooking fumes in restaurant kitchens in Norway. Annals of Occupational Hygiene, 46, 395-400.

Szigeti, T., et al. (2016). Oxidative potential and chemical composition of PM 2.5 in office buildings across Europe - the OFFICAIR study. Environment International, 92, 324-333.

Tao, H., Fan, Y., Li, X., et al. (2015). Investigation of formaldehyde and TVOC in underground malls in Xi' an, China: Concentrations, sources, and affecting factors. Building and Environment, 85, 85-93.

Taylor, J., Shrubsole, C., Davies, M., Biddulph, P., Das, P., Hamilton, I., Vardoulakis, S., Mavrogianni, A., Jones, B., \& Oikonomou, E. (2014). The modifying effect of the building envelope on population exposure to PM 2.5 from outdoor sources. Indoor Air, 24, 639-651. https://doi.org/ 10.1111/ina.12116

Uchiyama, S., Tomizawa, T., Tokoro, A., Aoki, M., Hishiki, M., Yamada, T., Tanaka, R., Sakamoto, H., Yoshida, T., Bekki, K., Inaba, Y., Nakagome, H., \& Kunugita, N. (2015). Gaseous chemical compounds in indoor and outdoor air of 602 houses throughout Japan in winter and summer. Environmental Research, 137, 364-372. https://doi.org/10.1016/j. envres.2014.12.005

Ugranlı, T., Toprak, M., Gursoy, G., Cimrin, A. H., \& Sofuoglu, S. C. (2015). Indoor environmental quality in chemistry and chemical engineering laboratories at Izmir Institute of Technology. Atmospheric Pollution Research, 6, 147-153.

Unsaldi, E., \& Çiftçi, M. K. (2010). Formaldehyde, usage areas, risk group, harmful effects and protective precautions. Journal of YYU Veterinary Faculty, 2, 71-75.

Wallace, L. A., Emmerich, S. J., \& Howard-Reed, C. (2002). Continuous measurements of air change rates in an occupied house for 1 year: The effect of temperature, wind, fans, and Windows. Journal of Exposure Analysis and Environmental Epidemiology, 12, 296-306.

Wang, S. (2012). Effects of surface roughness on the indoor particle deposition rate constant. Mechanical and Aerospace Engineering- Dissertations Paper 68. Available: https://surface.syr. edu/mae_etd $/ 68$

Wei, W., Ramalho, O., Derbez, M., Riberon, J., Kirchner, S., \& Mandin, C. (2016). Applicability and relevance of six indoor air quality indexes. Building and Environment, $109,42-49$.

WHO. (2010). New Guidelines for Selected Indoor Chemicals Establish Targets at Which Health Risks are Significantly Reduced. Available https://www.euro.who.int/_data/assets/ pdf_file/0004/128605/Factsheet_indoor_chem_15_Dec_10. pdf (accessed on 29 April 2020).

WHO. (2017). Evolution of WHO air quality guidelines: Past, present, future, WHO Regional Office for Europe, Denmark. 
Available http://www.euro.who.int/_data/assets/pdf_file/ 0019/331660/Evolution-air-quality.pdf

Wiglusz, R., Sitko, E., Nikel, G., Jarnuszkiewicz, I., \& Igielska, B. (2002). The effect of temperature on the emission of formaldehyde and volatile organic compounds (VOCs) from laminate flooring - Case study. Building and Environment, 37, 41-44.

Wu, Y., Lu, Y., \& Chou, D. (2018). Indoor air quality investigation of a university library based on field measurement and questionnaire survey. International Journal of Low-Carbon Technologies, 13, 148-160.

Xue, Y., Ho, S. S. H., Huang, Y., Li, B., Wang, L., Dai, W., et al. (2017). Source apportionment of VOCs and their impacts on surface ozone in an industry city of Baoji. Northwestern China. Scientific Reports, 7, 9979.

Yalçin, N. (2017). Environmental modeling and simulator development for gas sensors and measurement systems, PhD Thesis 2017; Sakarya University, Turkey.

Yang, Z. (2017). Indoor air pollution and preventions in college libraries. IOP Conference Series: Earth and Environmental Science, 64, 1-7.
Zhang, Y., Mu, Y., Liu, J., \& Mellouki, A. (2012). Levels, sources and health risks of carbonyls and BTEX in the ambient air of Beijing, China. Journal of Environmental Sciences, 24, 124-130.

Zhang, Z. B. (2019). The effect of library indoor environments on occupant satisfaction and performance in Chinese universities using SEMs. Building and Environment, 150, 322-329.

Zhou, C., Zhan, Y., Chen, S., Xia, M., Ronda, C., Sun, M., Chen, H., \& Shen, X. (2017). Combined effects of temperature and humidity on indoor VOCs pollution: Intercity comparison. Building and Environment, 121, 26-34.

Publisher's Note Springer Nature remains neutral with regard to jurisdictional claims in published maps and institutional affiliations. 